\title{
Phytoliths produced by common bean (Phaseolus vulgaris L.), achira (Canna indica L.), and squash (Cucurbita ficifolia Bouché), crop species from Boyacá, Colombia
}

\author{
Nataly Poveda-Díazi, *, María Eugenia Morales-Puentes ${ }^{1}$, Gregory Vaughan² \\ ${ }^{1}$ Grupo de Investigación SisBio, Herbario UPTC, Escuela de Ciencias Biológicas, Facultad de Ciencias Básicas, \\ Universidad Pedagógica y Tecnológica de Colombia, Tunja, Boyacá, Colombia \\ ${ }^{2}$ Grupo Interdisciplinario de Investigaciones Arqueológicas e Históricas, UPTC, Escuela de Ciencias Sociales, \\ Facultad de Ciencias de la Educación, Universidad Pedagógica y Tecnológica de Colombia, Tunja, Boyacá, Colombia
}

\begin{abstract}
Silica structures were analyzed in three species used by both pre-Hispanic and present-day populations in central Colombia: squash, common bean, and achira. In squash (Cucurbita ficifolia Bouché), structures were found in leaves and fruit epidermis, with undulated scalloped phytoliths and trichome forms. In achira (Canna indica L.), globular phytoliths with circular ornamentation in the center were found in leaves and corresponded to the Globulolita morpho-tribe. In common bean (Phaseolus vulgaris L.), elongated phytoliths with hooked ends were found on leaves and belonged to the Capilusita morpho-tribe. Through the standardization of the phytolith extraction protocol (dry ashing method), we established that leaves are the structures with the highest content of phytoliths in the species studied.
\end{abstract}

Key words: Silicophytoliths, morphotypes, Andean crops.

Fitolitos producidos por el fríjol (Phaseolus vulgaris L.), la achira (Canna indica L.) y la calabaza (Cucurbita ficifolia Bouché), especies alimenticias estudiadas en Boyacá, Colombia

\section{Resumen}

Se analizaron las estructuras silíceas en tres especies consideradas de uso prehispánico y actual en el centro de Colombia: calabaza, fríjol y achira. En la calabaza (Cucurbita ficifolia Bouché) se encontraron fitolitos festoneados, con ondulaciones, en forma de tricoma en hojas y epidermis del fruto. En las hojas de achira (Canna indica L.) se encontraron fitolitos globulares con ornamentación circular en el centro que correspondían a la morfotribu Globulolita. En las hojas de fríjol (Phaseolus vulgaris L.) se encontraron fitolitos de cuerpos alargados con terminación en forma de gancho pertenecientes a la morfotribu Capilusita. Mediante la estandarización del protocolo de extracción de fitolitos (dry ashing method) se estableció que la hoja fue la estructura donde se encontró el mayor contenido de fitolitos en estas especies.

Palabras clave: silicofitolitos, morfotipos, cultivos andinos.

\section{Introduction}

Phytoliths are structures resulting from the accumulation of oxalate, carbonate, or silica inclusions in cell walls or in entire cells from different tissues. Silica phytoliths are frequent in the plant epidermis, where both epidermal cells and specialized cells (occlusive cells, trichomes, etc.) undergo this deposition process. This mineralization is the result of the basic plant function of water absorption from the soil (Bowdery, 1998).

Silicophytoliths are common in leaves, floral parts, wood, and bark, and vary in form and size. Phytolith morphology is species-specific. It is possible that phytoliths carry out functions of physical support, resistance, or defense (Piperno, 1988a).
There are several factors that affect phytolith production in a given plant, among them, taxonomic (genetic) predisposition of the plant, age, climate, and soil composition. The availability of large amounts of water and the organic matter content of the soil also favor biomineralization processes, and hence the production of phytoliths (Parry \& Smith, 1958). These environmental conditions can influence phytolith production levels and, in rare cases, the pattern of phytolith deposition in the plant (Piperno, 1988b). This is the case, for example, of

\footnotetext{
*Corresponding author:

Nataly Poveda-Díaz, nataly.poveda@uptc.edu.co

Received: August 26, 2015

Accepted: January 20, 2016
} 
leguminous plants, which always silicify the sclerenchyma tissue, regardless of whether phytolith production is high or low (Piperno, 1988b).

The interest on phytoliths studies has been rising due to their presence in numerous plant families and to the possibility of establishing whether a given taxon produces these structures or not (Piperno, 1988b). In this sense, Zurro (2006) mentions the presence of intracellular silica not only in angiosperms, but also in mosses, horsetails, ferns, and conifers, as well as the tendency of herbaceous plants to produce more phytoliths than woody taxa. It should be noted that most studies have centered on cereals given their socioeconomic, historic, and botanic importance (Zurro, 2006).

Numerous studies show that silicophytolith production is widely distributed in plants, though more in certain families that in others, for example, in the Poaceae, the Arecaceae, the Cyperaceae, and the Asteraceae (Simkiss \& Wilbur, 1989). Afonso (2004) also detected phytoliths in the Lauraceae and the Boraginaceae, while Acosta, et al. (2011, 2013) described phytoliths in the Gunneraceae, and Fernández, et al. (2012) in the Ericaceae.

Since the pioneering studies of Ehrenberg (1854) and Douval-Jouve (1875), it has been known that not all plants are capable of absorbing and concentrating silica in their tissues, but in those plants that do possess this capacity, phytoliths acquire an indisputable taxonomic value (Bertoldi del Pomar, 1975). Furthermore, silicophytoliths remain in soils after plants die because of their chemical characteristics resistant to decomposition processes (Bertoldi de Pomar, 1975). The analysis of these structures is a new approach in paleoenvironmental reconstruction, as well as in paleoclimate and paleoethnobotany, i.e., the use of flora by prehistoric human communities (Piperno, 1988a). Pearsall (1988), Piperno (1988a), and Powers-Jones (1992) mention that analysis of phytoliths and silica skeletons has been applied to archeological materials and sediments for years now, with increasingly frequent published results.

The presence of silica in the soil is the consequence of processes of lixiviation of siliceous minerals (quartz, feldspar, etc.), as well as the dissolution of previously formed silica biominerals (phytoliths, diatoms, sponge spicules, among others). These processes are influenced by factors such as topography, climate, soil parent material, and moisture (Zurro, 2006).

Phytoliths are a tool to study ancient vegetation and landscape (Piperno, 2006), due to their specificity for certain plant taxa (Erra, et al., 2006). Thus, phytolith analysis is currently used in paleobotany as one of the components in the reconstruction of past ecosystems as it offers a precise snapshot of the vegetation in a given moment in history (Erra, 2010). Phytoliths also allow investigators to study paleo diet and the relationship of prehistoric peoples with their surroundings. Many studies have focused on the reconstruction of plant communities, offering information on the large-scale events that have affected their flora (Alexandre, et al., 1997; Barboni, et al., 1999, 2007; Scott, 2002; Abrantes, 2003; Bremond, et al., 2008; Barboni \& Bremond, 2009). Though most phytoliths are not a diagnostic tool for a single taxon, and can only be used to reconstruct large ecological groups, their analysis does enables the detection of some unique morphotypes, and, therefore, more precise taxonomic diagnostics and paleoecological interpretations (Eichorn, et al., 1996; Acosta, et al., 2011, 2013; Fernández, et al., 2012).

Phytolith observation is a relatively new archeological tool, and methods have recently been developed for the analysis of these silica structures in the processing of coproliths, abdominal sediments, and dental calculus. Dental calculus serves as a direct tool to study part of the food, swallowed or not, consumed by human groups thanks to the microparticles that remain trapped in the process of calculus formation once the food product enters the mouth. Furthermore, dental calculus analysis offers a way to draw closer to the specific food choices of each individual. This individual choice becomes a key route to discover cultural practices and social identity expressed in daily life (Gil, 2011).

The present study was conducted in the framework of the project Alimentos Prehispánicos, Alimentos Promisorios that aimed at evaluating traditional indigenous crops of Boyacá, Colombia, in terms of their botanic, agronomical, and cultural significance. The project used bibliographic and field techniques to study crops that have been consumed in Boyacá for more than 8,000 years (Morcote, 1996).

\section{Materials and methods}

\section{Area of study}

Boyacá department, with a total area of 23,189 km², is located in the center of Colombia, on the Andean Eastern Cordillera bordering Santander and Norte de Santander departments to the north, Arauca and Casanare departments (and the Venezuelan border) to the east, Meta and Cundinamarca departments to the south, and Cundinamarca and Antioquia departments to the west (Figure 1).

Its economy is based on agriculture, mining, steel production, commerce, and tourism. The principal crops are potato, maize, onion, wheat, beans, and sugarcane.

Plant material for the present study was collected from different municipalities where the three species are found. Ethnobotanic visits were carried out to establish the traditional uses and practices surrounding these crops based on what peasant farmers reported, as well as to observe the fields in which they were being cultivated. 


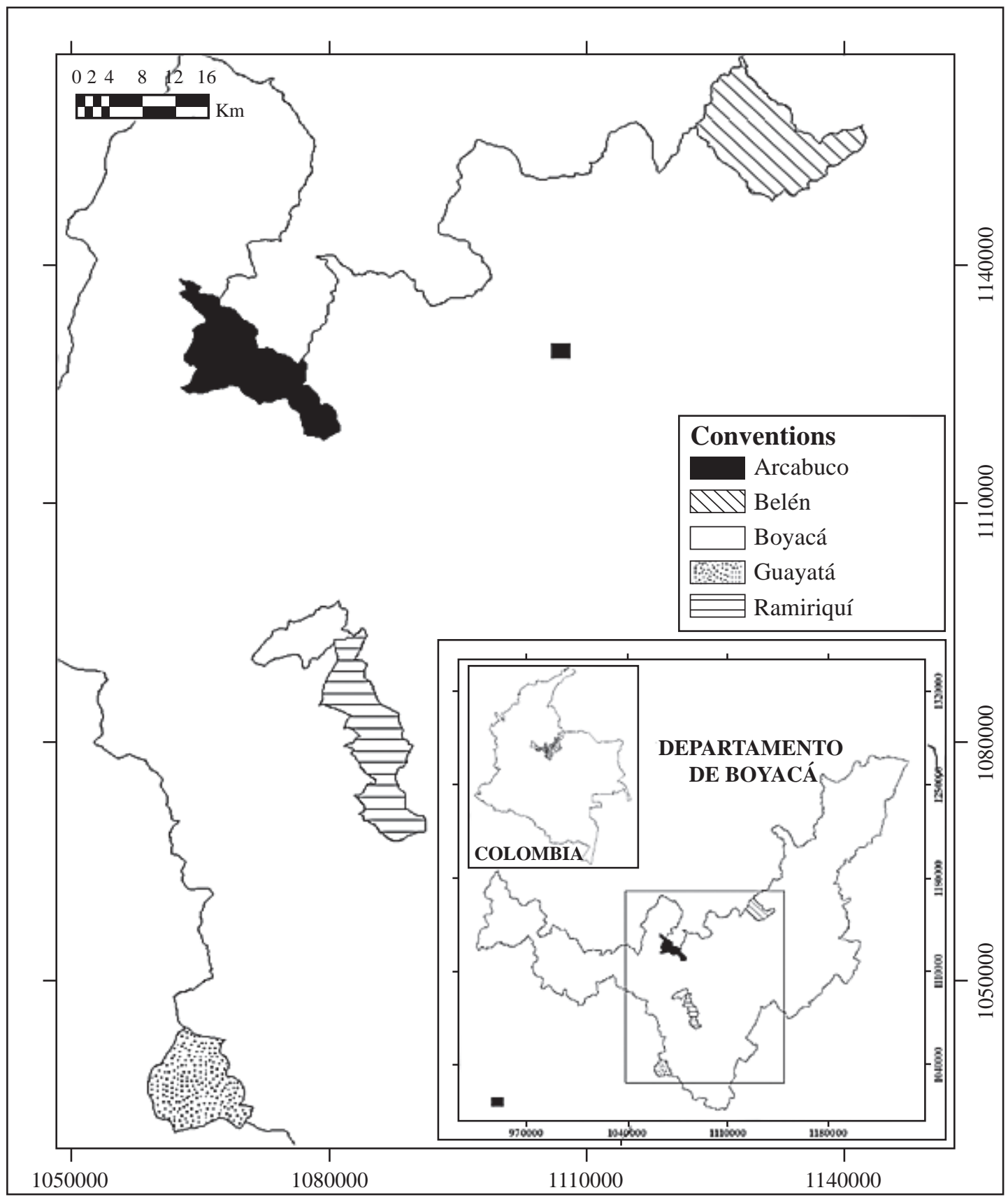

Figure 1. Map of the places where plant samples were collected: Ramiriquí, Boyacá, Arcabuco, Belén, and Guayatá, all in Boyacá, Colombia

\section{Fieldwork phase}

Collection of specimens and processing for herbarium. Exemplars were collected from Canna indica (Cannaceae), Cucurbita ficifolia (Cucurbitaceae), and Phaseolus vulgaris (Fabaceae) plant material, and each individual sample was placed between newspaper sheets. After pressing and drying, the material was managed according to standard herbarium procedures, and its identification confirmed by comparison with the reference collection, and consultation with experts, as well as virtual herbaria (COL, MO, and NY), web pages (The Plant List 2010; www.ipni.org; systematicplants.org), and the COL, UPTC, and FMB herbaria. Exemplars were entered into the UPTC Herbarium, and phytoliths were extracted from them. Characterization of silicophytoliths was performed following Parra \& Flórez (2001) methodology (Table 1), which is based strictly on morphological characteristics of phytoliths, thus allowing for their rapid identification and understanding. 
Table 1. Morphological classification of phytoliths from the Colombian Andes (taken from Parra \& Flórez, 2001).

\begin{tabular}{|c|c|c|}
\hline Morphotribes & Scheme forms & Form-Genre \\
\hline 1. Flabellulita & & 1) Verrugoflabellulita, 2) Psiloflabellulita, 3) Undolaflabellulita, 4) Fovaoflabellulita \\
\hline 2. Aculeolita & & 1) Verrugoaculeolita, 2) Psiloaculeolita, 3) Fovaoflabellulita \\
\hline 3) Prismatolita & & $\begin{array}{l}\text { 1) Psiloprismatolita, 2) Maculaprismatolita, 3) Faveoprismatolita, 4) Creteroprismatolita, } \\
\text { 5) Catenoprismatolita, 6) Espinoprismatolita, 7) Dentinoprismatolita, 8) Undolaprismatolita }\end{array}$ \\
\hline 4) Estrobilolita & & 1) Psiloestrobilolita, 2) Faveoestrobilolita, 3) Undolaestrobilolita \\
\hline 5) Braquiolita & & $\begin{array}{l}\text { 1) Faveobraquiolita, 2) Espinobraquiolita, 3) Verrugobraquiolita, 4) Psilobraquiolita, 5) } \\
\text { Sculptubraquiolita, 6) Recticulobraquiolita, 7) Undolabraquiolita, 8) Sulcabraquiolita }\end{array}$ \\
\hline 6) Elipsoidita & & $\begin{array}{l}\text { 1) Unduloelipsoidita, 2) Psiloelipsoidita, 3) Creteroelipsoidita, 4) Alataelipsoidita, 5) } \\
\text { Verrugoelipsoidita, 6) Foveoelipsoidita }\end{array}$ \\
\hline 7) Halteriolita & & 1) Psilohalteriolita, 2) Verrugohalteriolita \\
\hline 8) Bilobulita & & $\begin{array}{l}\text { 1) Psilobilobulita, 2) Creterbilobulita, 3) Verrugobilobulita, 4) Foveobilobulita, 5) Macubilobulita, } \\
\text { 6) Espinobilobulita }\end{array}$ \\
\hline 9) Doliolita & & 1) Psilodoliolita, 2) Creterodoliolita, 3) Foveodoliolita \\
\hline 10) Clavaelita & & 1) Psiloclavaelita, 2) Foveoclavaelita, 3) Undolaclavaelita, 5) Verrugoclavaelita \\
\hline 11) Petesusita & & $\begin{array}{l}\text { 1) Psilopetesusita, 2) Foveopetesusita, 3) Maculapetesusita, 4) Crateropetesusita, } \\
\text { 5) Undolapetesusita, 6) Verrugopetesusita }\end{array}$ \\
\hline 12) Globulolita & & $\begin{array}{l}\text { 1) Psiloglobulolita, 2) Maculaglobulolita, 3) Verrugoglobulolita, 4) Foveoglobulolita, 5) } \\
\text { Annuloglobulolita, 6) Undologlobulolita, 7) Alatoglobulolita }\end{array}$ \\
\hline 13) Longolita & & 1) Psilolongolita, 2) Undolalongolita, 3) Verrugolongolita, 4) Lanvalongolita, 5) Craterolongolita \\
\hline 14) Cymbaita & & 1) Psiloecymbaita, 2) Verrugocymbaita \\
\hline 15) Cylindrita & & 1) Verrugoyilindrita, 2) Esferocylindrita \\
\hline 16) Triangulita & & $\begin{array}{l}\text { 1) Psilotriangulita, 2) Verrugotriangulita, 3) Foveotriangulita, 4) Craterotriangulita, 5) } \\
\text { Reticutriangulita }\end{array}$ \\
\hline 17) Capilusita & & 1) Psilacapilusita, 2) Denticapilusita, 3) Estriacapilusita \\
\hline 18) Florisita & & 1) Psiloflorisita \\
\hline 19) Amorfolita & & Unknown or unclear shape. \\
\hline
\end{tabular}




\section{Laboratory phase}

Phytolith extraction. Samples were taken from leaves and edible parts of the plants (fruits or rhizomes), with three replications per organ in each plant, and processed in the oven of the UPTC Herbarium. The botanical material was then washed with distilled water and allowed to air dry. Phytoliths were extracted following the protocols of Piperno (1998a) and Zucol (1999) known as the dry ashing method (Morcote, 2008).

Rhizome, leaf, and fruit samples were ground and placed in crucibles at $500^{\circ} \mathrm{C}$ for three hours, after which they were allowed to cool for 12-24 hours. These carbonized samples were then placed in Falcon tubes with $10 \mathrm{~mL}$ of $10 \%$ $\mathrm{HCl}$ solution to eliminate organic matter and calcareous structures. The tubes were then placed in a hot water bath at $70^{\circ} \mathrm{C}$ for 20 minutes, after which they were decanted. Samples were then washed with distilled water, centrifuged at $3500 \mathrm{rpm}$ for five minutes, and decanted again. They were again washed with distilled water, centrifuged at 3500 rpm for five minutes, and decanted. After this, $50 \% \mathrm{H}_{2} \mathrm{O}_{2}$ was added to the samples, they were heated in a water bath for 20 minutes, and once again centrifuged at 3500 rpm for five minutes.

The samples were decanted again, washed with distilled water, and centrifuged for five minutes at $3500 \mathrm{rpm}$. They were agitated in a vortex after adding $10 \mathrm{~mL}$ of $90 \%$ alcohol, and centrifuged at $3500 \mathrm{rpm}$ for five minutes. This last step in the vortex was repeated a second time, after which the samples were transferred to Eppendorf tubes. A small sample was taken with a capillary tube and mounted in a circle on a slide. This slide was left on a hot plate for a few minutes to accelerate drying, and then two drops of Entelan were added to the sample which was subsequently covered with the slide cover and left like this for three days.

\section{Results}

We identified the samples analyzed. Silica was scarce in fruits and rhizomes. The samples with the highest number of silicophytoliths were leaves (Table 2), which coincides with Zucol \& Brea findings (2005).

Diagnostic phytoliths for $C$. indica belong to the Globulolita morphotribe, Macula-globulolita morphogenus, according to the classification of Parra \& Flórez (2001). Following the ICP international nomenclature code they are smooth or sometimes flattened globular structures. They normally occur together in groups of two to thirty globules (rarely alone), with transparent to brownish coloring. In the center they have a circular ornamentation (Figure 2).

Squash leaves present phytoliths in the form of solid and segmented trichomes with a wide base and a pointed end. They are classified in the Clavaelita morphotribe, Undolaclavaelita morphogenus. Both short and long phytoliths were found, some complete and some fragmented. They were abundant in the samples processed (Figure 3).

We found scalloped phytoliths diagnostic of the Cucurbita genus, belonging to the Globulita morphotribe and the Verrugo-globulita morphogenus (Figure 4).

Elongated structures terminating in acute angle hook forms were found in leaves of common bean Phaseolus vulgaris $\mathrm{L}$. The general form corresponded to a trichome with smooth edges and without ornamentation. The color ranged from brown to transparent. These phytoliths belong to the Capilusita morphotribe, Psilocapilusita morphogenus (Figure 5).

\section{Discussion}

Phytoliths are produced by many plant families, and some of them are taxonomically diagnostic because they have unique morphological characteristics that arise from their

Table 2. Sample information including georeferenciation, plant part sampled, and phytolith classification according to Parra \& Flórez (2001) and the ICP international nomenclature code.

\begin{tabular}{|c|c|c|c|c|c|c|c|}
\hline Municipality & Rural subdivision & Species & $\begin{array}{c}\text { Altitude } \\
\text { (masl) }\end{array}$ & Georeference & Plant part & $\begin{array}{c}\text { Phytolith } \\
\text { morphotribe }\end{array}$ & $\begin{array}{c}\text { Phytolith } \\
\text { morphogenus }\end{array}$ \\
\hline Arcabuco & Monte Suárez & Squash & 2456 & $\begin{array}{c}5^{\circ} 43^{\prime} 41.214^{\prime \prime} \mathrm{N} \\
73^{\circ} 29^{\prime} 24.408 ” \mathrm{~W}\end{array}$ & Leaf & Clavaelita & Undolaclavaelita \\
\hline Arcabuco & Quirvaquirá & Achira & 2937 & $\begin{array}{c}\text { 5041'55.4”N } \\
73^{\circ} 22^{\prime} 10.3 ” \mathrm{~W}\end{array}$ & Leaf & Globulolita & Maculaglobulolita \\
\hline Belén & Centro & $\begin{array}{l}\text { Common } \\
\text { bean }\end{array}$ & 1851 & $\begin{array}{c}4^{\circ} 57.533^{\prime} \mathrm{N} \\
73^{\circ} 27.896^{\prime} \mathrm{W}\end{array}$ & Leaf & Capilusita & Psilocapilusita \\
\hline Ramiriquí & Caicedos & $\begin{array}{l}\text { Common } \\
\text { bean }\end{array}$ & 2291 & $\begin{array}{c}5^{\circ} 23^{\prime} 35.0^{\prime \prime} \mathrm{N} \\
73^{\circ} 20^{\prime} 31.2^{\prime \prime} \mathrm{W}\end{array}$ & Leaf & Capilusita & Psilocapilusita \\
\hline Guayatá & Ciavita 2 & Achira & 1861 & $\begin{array}{c}4^{\circ} 57.531^{\prime} \mathrm{N} \\
73^{\circ} 27.850^{\prime} \mathrm{W}\end{array}$ & Leaf & Globulolita & Maculaglobulolita \\
\hline Boyacá & Soconzaque & $\begin{array}{l}\text { Common } \\
\text { bean }\end{array}$ & 2458 & $\begin{array}{c}5^{\circ} 26{ }^{\prime} 30.414 ” \mathrm{~N} \\
73^{\circ} 23 \text { '24.822”W }\end{array}$ & Leaf & Capilusita & Psilocapilusita \\
\hline Boyacá & Soconzaque & Squash & 2458 & $\begin{array}{c}5^{\circ} 26^{\prime} 30.414^{\prime \prime} \mathrm{N} \\
73^{\circ} 23^{\prime} 24.822^{\prime \prime} \mathrm{W}\end{array}$ & Fruit & Globulolita & Verrugoglobulolita \\
\hline
\end{tabular}




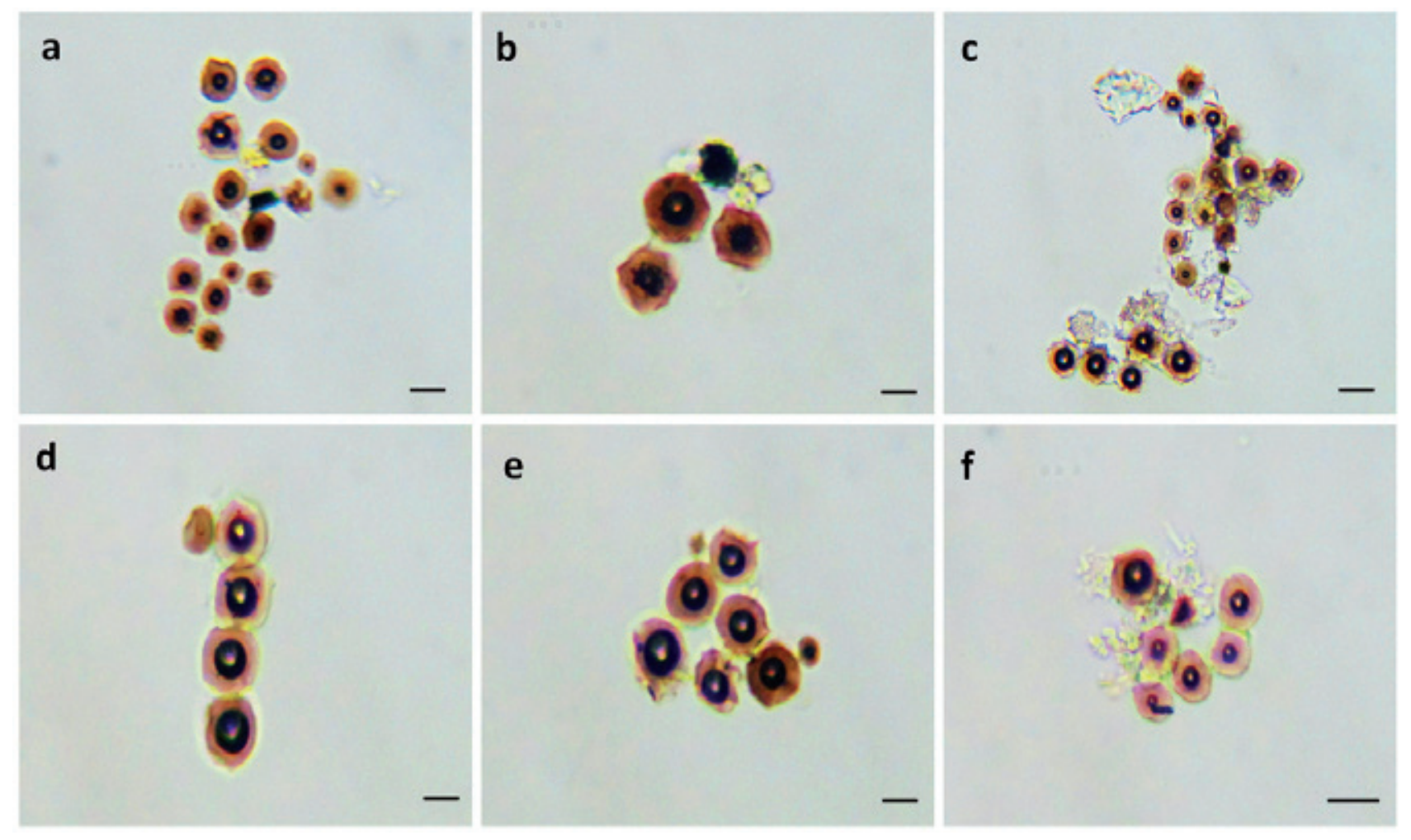

Figure 2. Phytoliths found in achira leaves (Canna indica L.). a) Major axis: $97.56 \mu \mathrm{m}$, minor axis: $82.44 \mu \mathrm{m}$; b) $31.26 \mu \mathrm{m}, 10.45 \mu \mathrm{m}$; c) $36.1 \mu \mathrm{m}, 9.99 \mu \mathrm{m}$; d) $38.58 \mu \mathrm{m}, 14.19 \mu \mathrm{m}$; e) $25.53 \mu \mathrm{m}, 24.91 \mu \mathrm{m}$; f) $24.96 \mu \mathrm{m}, 23.58 \mu \mathrm{m}$. Scale: $10 \mu \mathrm{m}$ by $40 \mathrm{X}$.

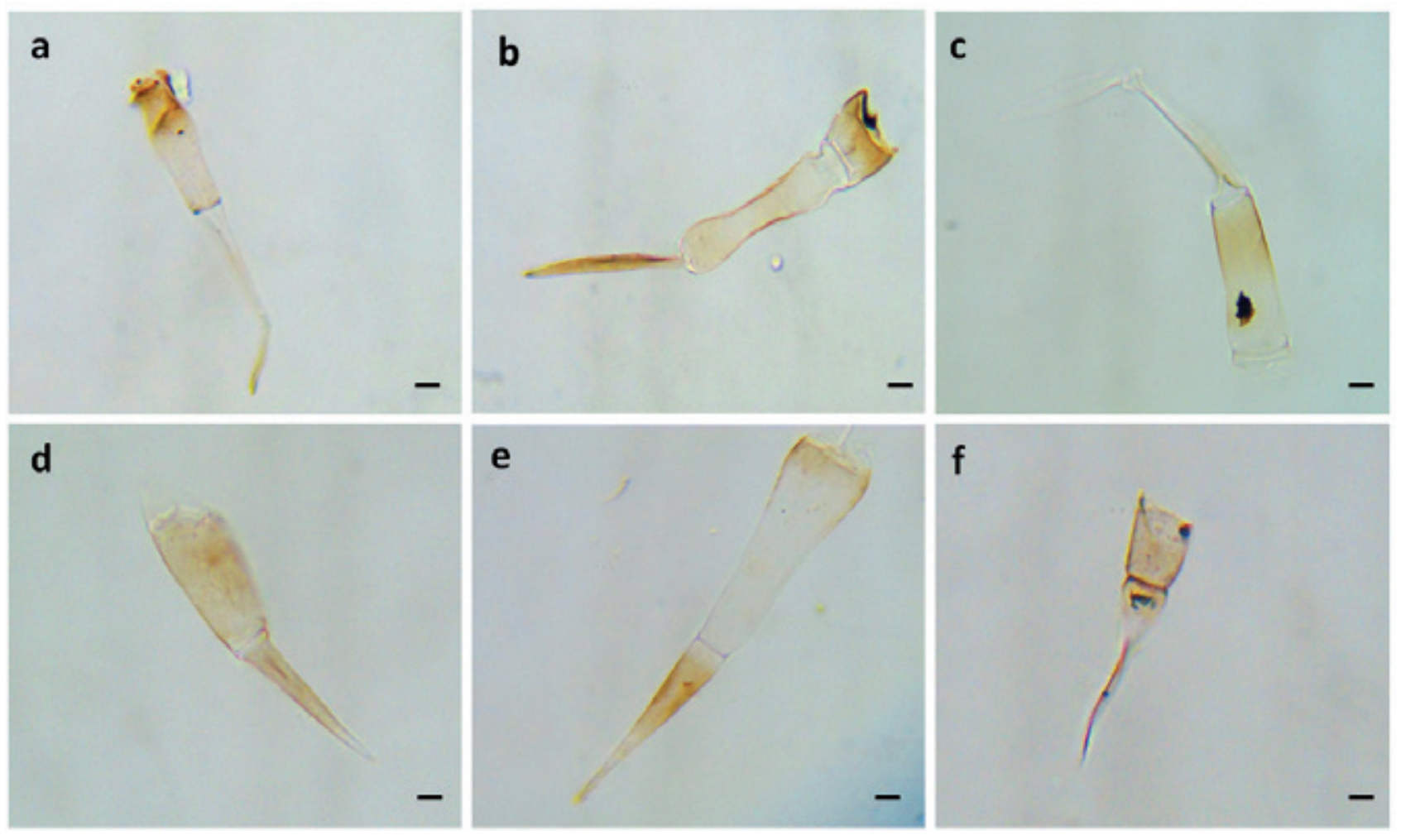

Figure 3. Squash leaf phytoliths (Cucurbita ficifolia Bouché. a) $137.97 \mu \mathrm{m}, 20.58 \mu \mathrm{m}$; b) $88.23 \mu \mathrm{m}, 16.3 \mu \mathrm{m}$; c) $123.78 \mu \mathrm{m}, 23.78 \mu \mathrm{m}$; d) $100.7 \mu \mathrm{m}, 21.48 \mu \mathrm{m}$; e) $93.6 \mu \mathrm{m}, 18.54 \mu \mathrm{m}$; f) $53.32 \mu \mathrm{m}, 13.64 \mu \mathrm{m}$. Scale: $10 \mu \mathrm{m}$ by $40 \mathrm{X}$. 


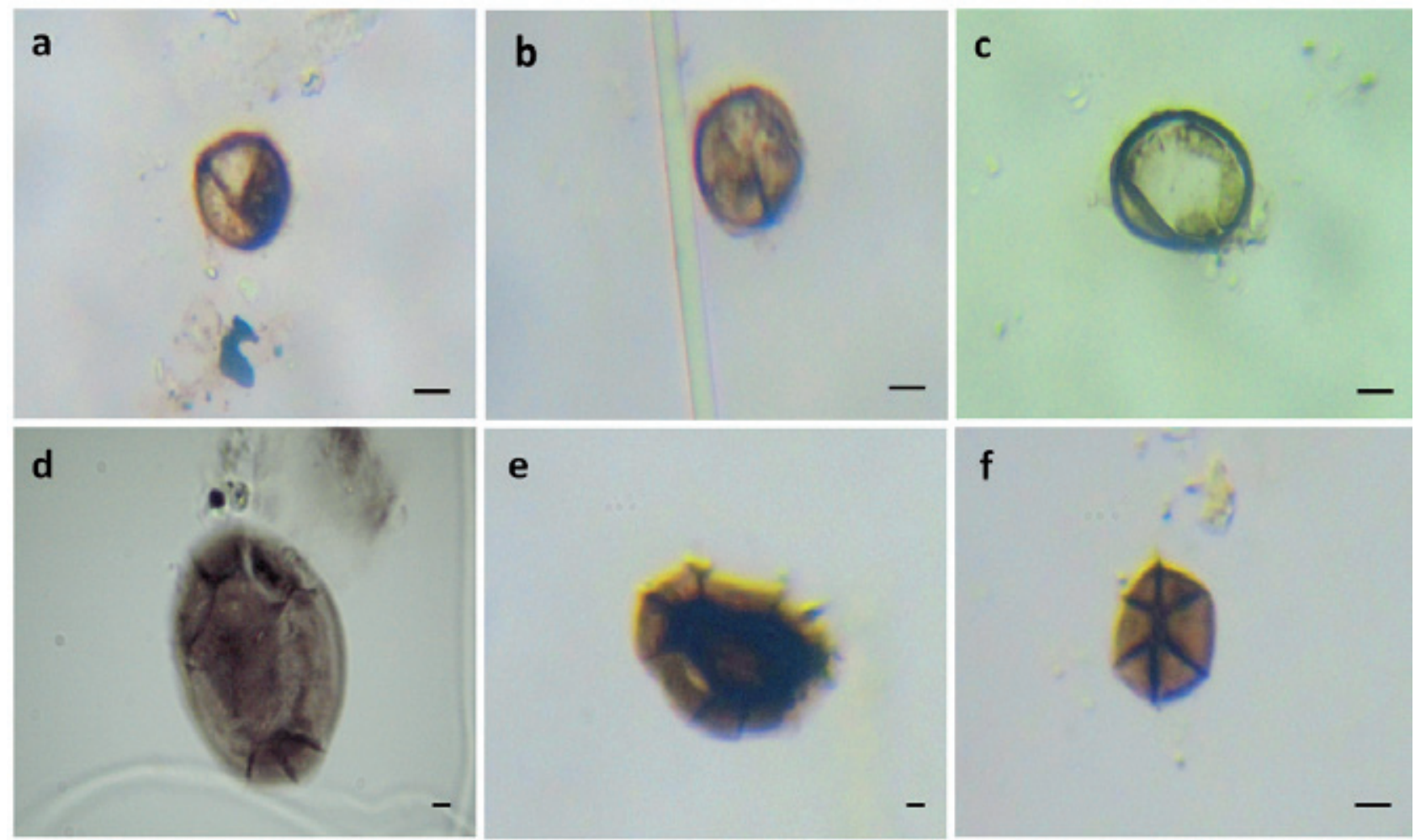

Figure 4. Phytoliths from the epidermis of squash fruit (Cucurbita ficifolia Bouché). a) $23.25 \mu \mathrm{m}, 21.63 \mu \mathrm{m}$; b) $47.97 \mu \mathrm{m}, 28.62 \mu \mathrm{m}$; c) $38.7 \mu \mathrm{m}, 23.86 \mu \mathrm{m}$; d) $21.63 \mu \mathrm{m}, 16.88 \mu \mathrm{m}$; e) $22.24 \mu \mathrm{m}, 21.26 \mu \mathrm{m}$; f) $32.93 \mu \mathrm{m}, 21.14 \mu \mathrm{m}$. Scale: $10 \mu \mathrm{m}$ by $40 \mathrm{X}$.

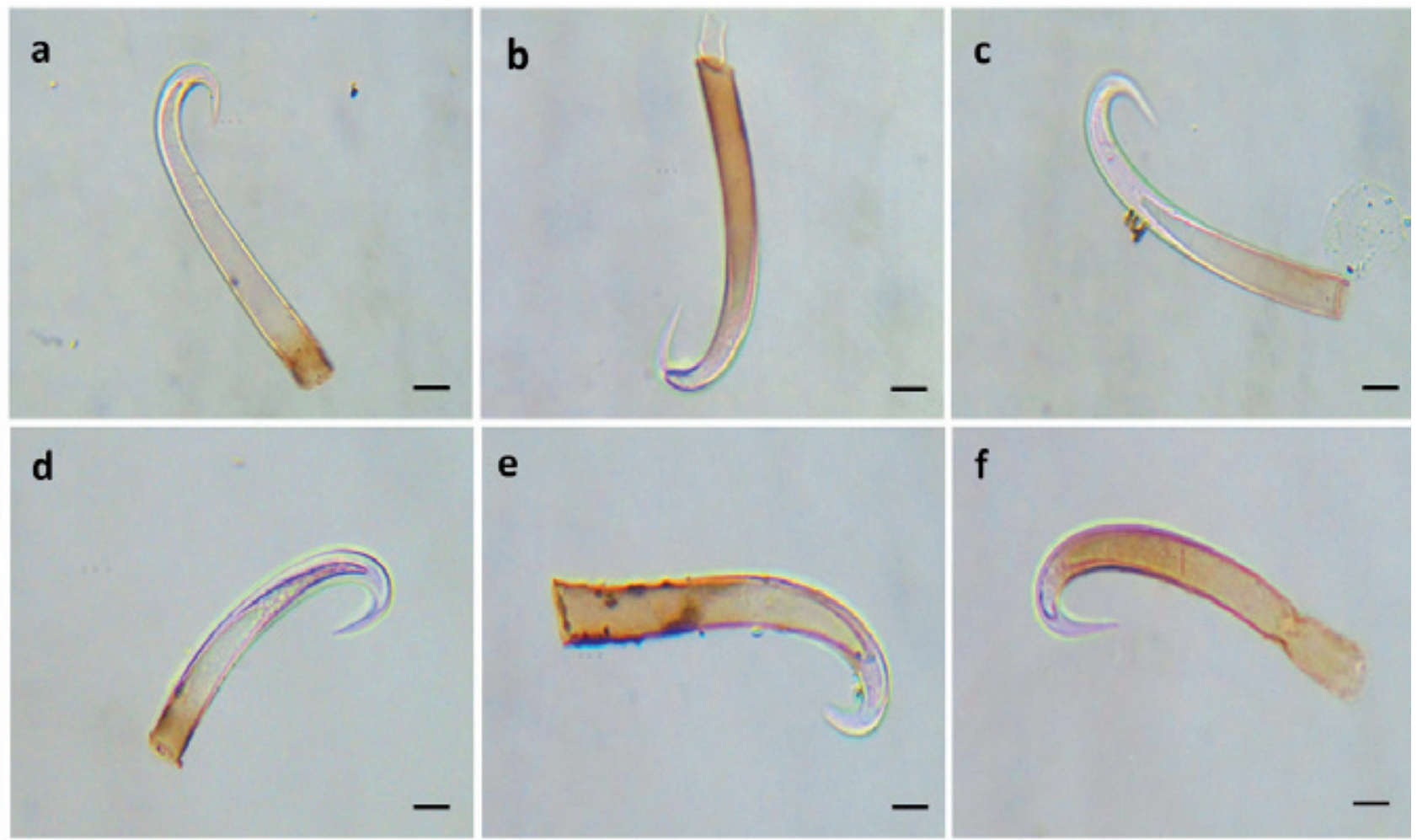

Figure 5. Phytoliths from leaves of common bean Phaseolus vulgaris L.; a) $92.4 \mu \mathrm{m}, 12.26 \mu \mathrm{m}$; b) $78.2 \mu \mathrm{m}, 9 \mu \mathrm{m}$; c) $88.64 \mu \mathrm{m}, 10,32 \mu \mathrm{m}$; d) $102.96 \mu \mathrm{m}, 9.94 \mu \mathrm{m}$; e) $57.37 \mu \mathrm{m}, 8.51 \mu \mathrm{m}$; f) $93.5 \mu \mathrm{m}, 11.9 \mu \mathrm{m}$. Scale: $10 \mu \mathrm{m}$ by $40 \mathrm{X}$. 
genesis. There are limitations to the classification based on phytoliths, since there exist both redundancy (different plant species bearing phytoliths of similar morphology) and multiplicity (various phytolith morphologies in the same species). These limitations have led some authors to propose a non-taxonomic classification based on the form of the phytoliths themselves, with less emphasis on the form of the plants producing them, allowing a more general taxonomic classification for producer organisms at the sub-family, family, and order levels (Rovner, 1983; Piperno, 1988a).

Until a few years ago there was no consensus on how to attain a universal systematization of phytoliths. This topic has been addressed by several authors (Zucol, 1995, 1999; Bowdery, 1998), and in year 2000 a commission was formed that announced a protocol for naming phytoliths (Madella, et al., 2002, 2005), in which the foundation was laid for morphotype nomenclature, but its application has had numerous problems, and it did not gain general acceptance among scientists dedicated to the study of these microremains (Era, 2010). It was necessary then, to establish classifying criteria for a phytolith systematization that may allow for a precise treatment and definition of categories (Zucol \& Brea, 2005).

Phytoliths extracted from contemporary plants are used as a reference to assign botanical referents to phytolith morphotribes, since older specimens become harder to define taxonomically (Zurro, 2006).

The silicophytoliths found in present-day plants serve as a key to the fossil record, but not all plants produce them, and furthermore, phytoliths are not present at all stages of development, since silica is deposited gradually over the life of the plant. This means that the possibility of finding the structures in juvenile plants is low (as was confirmed in the present study in which phytoliths were scarce in younger plant material). Furthermore, the concentration of phytoliths in the plant and in the different plant parts varies according to the phenological stage (Bertoldi de Pomar, 1975; Zurro, 2006).

Such factors have negative repercussions for the realization of archeological studies based on dental calculus, because often the leaves, in which phytoliths are mostly present, are not the part of the plant that is consumed. Hence, there are few phytoliths found in dental calculus of human remains, and its analysis yields little information on prehistoric diets (Zurro, 2006). Consequently, for the study of paleo diet it may be more useful to analyze starch morphology in dental calculus.

The phytoliths we encountered in the fruit and leaves of squash coincided with those described by Bozarth (1987), who points out that Cucurbita sp. fruits produce large spherical phytoliths with undulated, deeply and regularly scalloped surfaces. To obtain these structures it was necessary to extract a piece of mature fruit skin, since the phytoliths are located in the pericarp, as noted by Holst \& Piperno (1998). It is not probable that these phytoliths are produced in other parts of the plant. Furthermore, Parry \& Smith (1958) noted that the highest production of silicophytoliths occurs at the end of the plant's life cycle. No phytoliths were found in roots or rhizomes of the three plants studied due to the low or nonexistent accumulation of silica in these parts (Chandler, et al., 2006), which confirms the tendency of plants to deposit silica in aerial parts for support purposes.

It can be that cell silicification in Cucurbita ficifolia fruits is a defensive response against herbivory. Phytoliths can constitute an imposing physical defense, especially if they are concentrated in external plant tissues. Silica is one of the few substances that are hard enough to grind and wear down tooth enamel, and in plants containing large quantities, it can also cause kidney damage and other urinary problems in primarily herbivorous animals (Piperno, et al., 2000). A plant may benefit from defending its fruit from consumption by microherbivores (pests), while at the same time allowing consumption by birds and macroherbivores, which would help the plant to disperse its seeds.

According to some other studies, and seemingly confirmed by the present study, phytoliths differ in size between domesticated and wild species of the Cucurbita genus. The absence of large, solid phytoliths in many varieties of domesticated Cucurbita appears to be related to changes in the structure of the fruit epidermis, and the production of phytoliths in the pericarp zone becomes less differentiated or is lost entirely in these domesticated individuals (Holst \& Piperno, 1998). These changes can result from the loss of herbivory pressure; Johns (1990) makes the analogy that the reduction of a physical defense in the process of squash domestication is similar to the reduction of the toxic chemical substances produced by other plant species when they are domesticated.

According to Piperno, et al. (2000), Cucurbita ficifolia has larger phytoliths than other known squash species. The explanation they offer is that cell size increases drastically under domestication, and that, therefore, phytoliths have more space to occupy in the plant tissue and thus increase considerably in size.

The same phytolith morphology may be produced by numerous species. This redundancy confirms the diagnostic shortcomings of phytoliths. In the present study there were similar phytoliths (in trichome form) in $P$. vulgaris and $C$. ficifolia, while $C$. indica presented distinctive globular phytoliths. When such similarities in form are found in the same botanical family, this permits the identification of a given morphogenus as emblematic of a certain family. But if similar phytoliths are found in species of different families, it is problematic to identify phytoliths with the plant generating them because of redundancy (Rovner, 1971). 
Studies conducted by Bozarth (1987) demonstrated that the distinctive silicified hook-shaped hairs produced on seed pods of Phaseolus vulgaris and Phaseolus lunatus can be diagnostic for this genus. However, Piperno (1988a) informed that non-segmented, curved, thin hairs, similar to those of Phaseolus, may occur in certain Neotropical species of the Aristolochiaceae, Boraginaceae, Moraceae, Fabaceae, and Urticaceae families.

The present study found that the plant part containing the highest number of phytoliths among the species studied were the leaves. Studies such as that of Ricci, et al. (2015) show that the concentration of silicophytoliths in plant structures is affected by factors such as the taxon under study. In this sense, phytolith production is abundant in monocots but variable among different dicot families.

This work contributes valuable information to the study of food crops used by pre-Hispanic cultures in Boyacá. To wit, phytolith analysis is not a promising indicator of paleo diet in the study of dental calculus because the consumed portion of most crop plants is not the phytolith-rich leaf, but rather the fruit or subterranean parts, which produce few or no phytoliths. Starch analysis might be a more robust diagnostic tool for the study of paleo diet by means of dental calculus.

\section{Acknowledgments}

The authors wish to thank the Universidad Pedagógica y Tecnológica de Colombia and its Biology laboratories, as well as the institution's Incitema Institute, Archeology Museum, and Herbarium. The research underlying this article was financed by the Alimentos Prehispánicos, Alimentos Promisorios project running from 2011 to 2013 (Colciencias-UPTC, Agreement 521 of 2010 of the Convocatoria del Banco de Proyectos de Investigación Científica y Tecnológica.) The authors especially wish to thank the peasant farmers of Arcabuco, Ramiriquí, Boyacá, Belén, and Guayatá for sharing their crops, their knowledge, and their experience. We also owe our thanks to the experts who shared their insights: G. Morcote, W. Posada, and A. Álvarez. Lastly, thanks go to H. Pradilla, E. Vera, D. Galindo, C.N. Díaz, P.A. Gil, J. Gil, C. Castro, W. Bravo, C. Cárdenas, D. Cárdenas, J. Tamayo, M. Cárdenas, L. Gutiérrez, S. Jiménez, and C. Fernández.

\section{Conflict of interests}

The authors declare no conflicts of interest of any kind.

\section{Bibliography}

Acosta, Y.C., Fernández, M.G., Arriaga, M.O. (2011). Descripción y cuantificación biomineral de Gunnera magellanica Lam. (Gunneraceae). Boletín de la Sociedad Argentina de Botánica. 46: 80.

Acosta, Y.C., Fernández, M.G., Arriaga, M.O. (2013). Comparación de la composición biomineral de cuatro especies del género Gunnera. Boletín de la Sociedad Argentina de Botánica. 48: 31.
Acosta, Y.C., Fernández, M.G., Arriaga, M.O. (2015) Estudio comparativo de la composición biomineral de cuatro especies del género Gunnera de la Argentina. Boletín de la Sociedad Argentina de Botánica. 50 (4): 481-492.

Alexandre, A., Meunier, J.D., Lezine, A.M., Vincens, A., Schwartz, D. (1997). Phytoliths as indicators of grassland dynamics during the late Holocene in intertropical Africa. Palaeogeography, Palaeoclimatology, Palaeoecology. 136: 213-229.

Afonso, J. (2004). Aportaciones del análisis de fitolitos, almidones y otros referentes microscópicos al estudio de la prehistoria y arqueología de las islas Canarias; resultados preliminares. Revista Rabona. 12: 69-96.

Barboni, D., Bonnefille, R., Alexandre, A., Meunier, J.D. (1999). Phytoliths as paleoenvironmental indicators, west side middle Awash valley, Ethiopia. Palaeogeography, Palaeoclimatology, Palaeoecology. 152: 87-100.

Barboni, D, \& Bremond L. (2009). Phytoliths of East African grasses: An assessment of their environmental and taxonomic significance based on floristic data. Review of Palaeobotany and Palynology. 158: 29-41.

Bertoldi de Pomar, H. (1975). Los silicofitolitos: sinopsis de conocimiento. Darwiniana 19 (2-4): 174-206.

Bowdery, D. (1998). Phytolith analysis applied to Pleistocene Holocene archaeological sites in the Australian arid zone. Bar International Series 695. Archaeopress, Oxford. p. 216.

Bozarth, S.R. (1987). Diagnostic opal phytoliths from rinds of selected Cucurbita species. American Antiquity. 52: 607-615.

Bremond, L., Alexandre, A., Peyron, O., Guiot, J. (2008). Definition of grassland biomes from phytoliths in West Africa. Journal of Biogeography. 35: 2039-2048.

Chandler, E.K., Pearsall, D., Zeidler, J. (2006). Root and tuber phytoliths and starch grains document manioc (Manihot esculenta), arrowroot (Maranta arundinacea) (Calathea sp.), at the Real Alto Site, Ecuador. Economic Botany. 60 (2): 103-120.

Douval-Jouve, M.J. (1875). Sur une forme de cellules épidermiques qui paraît propre aux Cypéracées. ComptesRendus Hebdomadaires des Seances de I'Academie des Sciences, Series de Sciences Naturelles. 75: 371-372.

Ehrenberg, C.G. (1854). Mikrogeologie. Leopold Voss, Leipzig. p. 354.

Eichorn, B., Hahn, H.P., Müller-Haude, P. (1996). Espace naturel, techniques agraires et végétation végétale en pays Kassena. Berichte des Sonderforschungsbereichs. 268 (7): 71-81.

Erra, G. (2010). Asignación sistemática y paleocomunidades inferidas a partir del estudio fitolítico de sedimentos cuaternarios de Entre Ríos, Argentina. Boletín de la Sociedad Argentina de Botánica. 45 (3-4): 309-319.

Erra, G., Zucol, A.F., Kröhling, D., Brea, M. (2006). Análisis fitolíticos en el loess del Pleistoceno tardío-Holoceno temprano en la provincia de Entre Ríos: resultados preliminares. III Congreso Argentino de Cuaternario y Geomorfología, Actas de Trabajo. 2 (13): 691-699. 
Fernández, M.G., Arriaga, M.O., Zucol, A.F. (2012). Leaf anatomy and biomineralization in Empetrum rubrum Valh ex Willd. (Ericaceae). Botánica Complutensis. 36: 113-121.

Gil, B.E. (2011). Fitolitos en cálculo dental de poblaciones tempranas del valle geográfico del río Cauca (500 a.C.500 d.C.). Aproximación a la paleodieta. Tesis de maestría. Facultad de Ciencias Humanas, Maestría en Antropología. Universidad Nacional de Colombia.

Holst, I., \& Piperno, D. (1998). Rind tissue structure and phytolith presence and morphology in the Cucurbitaceae. Manuscript on file at the Smithsonian Tropical Research Institute.

Johns, T. (1990). With bitter herbs they shall eat it. Chemical ecology and the origins of human diet and medicine. Tucson: University of Arizona Press.

Madella, M., Alexandre, A., Ball, T. (2002). International Code for Phytolith Nomenclature. $4^{\text {th }}$ International Meeting on Phytolith Research (Cambridge, England), Abstract: 8.

Madella, M., Alexandre, A., Ball, T. (2005). International Code for Phytolith Nomenclature. Annals of Botany. 96: 253-260.

Morcote, G. (1996). Evidencia arqueobotánica de cultígenos presentes en grupos Muiscas de la Sabana de Bogotá en los siglos VIII y XI. Bioantropología de la Sabana de Bogotá, Siglos VIII al XVI D.C. Instituto Colombiano de Antropología, Colcultura. p. 59-84.

Morcote, G. (2008). Antiguos habitantes en ríos de aguas negras. Ecosistemas y cultivos en el interfluvio AmazonasPutumayo. Colombia-Brasil. En: Colombia 2008. Universidad Nacional de Colombia. 19: 242.

Parra, L.N., \& Flórez, M.T. (2001). Propuesta de clasificación morfológica para los fitolitos altoandinos colombianos. Crónica Forestal y del Medio Ambiente. 16: 35-66.

Parry, D.W., \& Smith, F. (1958). Techniques for studying opaline silica in grass leaves. Annals of Botany. 22 (88): 543-549.

Pearsall, D. (1988). Interpreting the meaning of macroremain abundance: The impact of source and context. p. 97-118. En CA Hastorf y Vs Popper (Eds.) Current paleoethnobotany. Analytical methods and cultural interpretations of archaeological plant remains. Prehistoric Archeology and Ecology Series. University of Chicago Press.

Piperno, D.R. (1988a). Phytolith analysis: An archaeological and geological perspective. Academic Press/Harcourt Brace Jovanovich, New York (US). p. 280.

Piperno, D.R. (1988b). Prehistoria temprana de la península de Santa Elena, Ecuador. Cultura Las Vegas. Primer informe sobre los fitolitos de las plantas del sitio OGSE-80 y la evidencia del cultivo del maíz en el Ecuador. En KE Stothert (Ed.) Miscelánea Antropológica Ecuatoriana, serie monográfica. 10: 203-223.

Piperno, D.R. (2006). Phytoliths. A comprehensive guide for archeologists and paleoecologists. Altamira Press, Oxford.

Piperno, D., Andres, D.C., Stothert, K.E. (2000). Phytoliths in Cucurbita and other neotropical Cucurbitaceae and their occurrence in early archaeological sites from the lowland American tropics. Journal of Archaeological Science. 27: 193-208.

Powers-Jones, A. (1992). Great expectations: A short historical review of European phytolith systematics. En G Rapp y S Mulholland (Eds.) Phytolith systematics: Emerging issues. Advances in Archaeological and Museum Science. 1: 15-35.

Rovner, I. (1971). Potential of opal phytoliths for use in paleoecological reconstruction. Quaternary Research. 1: 343-359.

Rovner, I. (1983). Plant opal phytolith analysis: major advances in archaeobotanical researcher. p. 225-260. In Schiffer M (Ed.) Advances in archaeological method and theory. New York: Academic Press.

Scott, L. (2002). Grassland development under glacial and interglacial conditions in southern Agrecia: Review of pollen, phytolith and isotope evidence. Palaeogeography, Palaeoclimatology, Palaeoecology. 177: 45-57.

Simkiss, K., \& Wilbur, K.M. (1989). Biomineralization. Cell biology and mineral deposition, Academic Press, USA. p. 337.

The Plant List. (2010). A working list of all plants species, www. theplantlist.org. Fecha de consulta: 18 de julio de 2013.

Zucol,A.F. (1995). Microfitolitos: II. Análisis de las clasificaciones. Ameghiniana. 32 (3): 243-248.

Zucol, A.F. (1999). Fitolitos: hacia un sistema clasificatorio. Ameghiniana. 36 (4): Suplementos-Resúmenes: 43R.

Zucol, A.F., \& Brea, M. (2005). Sistemática de fitolitos, pautas para un sistema clasificatorio. Un caso en estudio en la formación Alvear (Pleistoceno inferior). Ameghiniana. 42 (4): 685-704.

Zurro, D. (2006). El análisis de fitolitos y su papel en el estudio del consumo de recursos vegetales en la prehistoria: bases para una propuesta metodológica materialista. Trabajos de Prehistoria. 63 (2): 35-54. 